Article

\title{
Integrated Water Resources Management in Federations: The Examples of Brazil and Switzerland
}

\author{
Graziele Muniz Miranda ${ }^{1}$ (D) and Emmanuel Reynard ${ }^{2, *}$ \\ 1 Federal Institute of Education, Science and Technology of São Paulo, Boituva 18550-000, Brazil; \\ gmunizmiranda@gmail.com \\ 2 Institute of Geography and Sustainability and Interdisciplinary Centre for Mountain Research, \\ Geopolis building, University of Lausanne, CH-1015 Lausanne, Switzerland \\ * Correspondence: emmanuel.reynard@unil.ch
}

Received: 21 May 2020; Accepted: 2 July 2020; Published: 4 July 2020

\begin{abstract}
International water institutions worldwide consider integrated water resources management (IWRM) to be the most sustainable way to manage water. Governments have modified their legal and institutional framework in order to apply integrated water management tools in the river basin. Institutional challenges are common in federations due to complex power sharing at national and subnational levels. This article discusses the implementation of the hegemonic model of IWRM in federations, based on a review of the literature for two different federal countries: Brazil and Switzerland. Due to the centralized character of Brazilian federalism, adjustments made in recent decades aimed to adapt the water management model through a hegemonic approach of participation and decentralization, shaped by international experiences and institutions. Some challenges concern vertical interplay, concerning coordination between levels and effective implementation of decentralization and participation. In contrast, Switzerland has a non-hegemonic model of water management, which is varied and fragmented throughout the country. As management is decided and applied locally, the main challenge concerns horizontal interplay, with regionalization and coordination of water uses.
\end{abstract}

Keywords: federalism; water management; river basin; participation

\section{Introduction}

In the last four decades, the international community has become aware that global water problems are multi-dimensional and multi-sectoral, involving multiple interests, agendas and causes. This complexity highlights the limits of centralized and sectorized management [1], and necessitates multi-stakeholder coordination during decision-making [2,3].

The concept of integrated water resources management (IWRM) emerged to promote the coordinated development and management of water, land and related resources. It aims to maximize the resultant economic and social welfare equitably, without compromising the sustainability of vital ecosystems [2]. IWRM applies to multiple water uses (horizontal integration) and many institutional levels (vertical integration) [4]. Since its inclusion in Chapter 18 of Agenda 21, adopted at the Earth Summit in Rio in 1992, the concept has spread across the world and has been promoted by several international institutions, notably Global Water Partnership (GWP) and the World Bank. Even if multi-sectoral water management at the river basin level has been used for at least 100 years [4], according to international reports, only the current conception has normative characteristics $[5,6]$.

IWRM is characterized by the following general water management principles: the hydrological river basin as the spatial unit for management; stakeholder participation; financing mechanisms; 
monitoring; and development of a database system. These principles are to be formalized by specific legislation, and executed by watershed institutions $[2,7,8]$.

Since the 1990s, many countries have adopted the concept in their national legislation and changed their institutional frameworks $[2,9,10]$. Some unitarian countries, such as France, have institutionalized watershed institutions throughout the country. Because federations share power and autonomy between national and subnational levels, as defined by a federal constitution, the creation of this kind of entity represents the addition of another management structure to existing ones [11]. In decentralized federations, the decision-making process tends to be complicated. That is because each subnational level has considerable autonomy in deciding and executing national public policies, which consequently usually results in different examples of water management.

The exact meaning of integrated in 'Integrated Water Resources Management (IWRM)' is often not clear in national legislations. Even if the IWRM is a normative concept, water management is a socio-political process, wherein integration takes multiple forms and meanings [4] depending on the interests and motives of the stakeholders. Based on a review of the literature, this paper analyzes the main characteristics of IWRM implementation in a developing, transitional and federal country, Brazil, as well as the interest in, and strategies behind, IWRM in Switzerland, a federal country with less international economic dependence and greater political stability. We discuss the differences between the two federations, and how they are linked to the characteristics of their water resource management systems.

First, we discuss the scales and levels of IWRM implementation (Section 2). Section 3 gives an overview of the main challenges in its execution in federal countries. Section 4 describes the changes in integrated water resources management taking place in Brazil in recent decades, through a period of re-democratization (Section 4.1), and the relationship between federalism and the diversity of water management models in Switzerland (Section 4.2). Finally, we discuss factors that may influence the future development and implementation of IWRM in the two countries (Section 5).

\section{Scales and Levels of IWRM Implementation}

In recent decades, international water and financial institutions [5,6] have considered the river basin a "naturally given" region, and thus the appropriate unit based on the rationality of natural science [7]. In order to adopt it, governments have ratified legislation and policy documents, and established institutional frameworks.

Social and political science theorists have contested the choice of the river basin as a neutral and natural perimeter $[7,8,11,12]$. Besides containing biophysical characteristics, a river basin exhibits an ensemble of socioeconomic and political-administrative scales $[7,9,13]$. Stakeholders can create, constrain and shift scales to suit their own interests $[9,10,12,13]$. The choice of scale may reflect the social, political and economic context [9], and changing power and authority, as different spatial levels equate to differences in access to resources, data interpretation, assessments, knowledge, decision-making and policy implementation $[9,12]$.

A parallel can be drawn between the current paradigm of the river basin as a water management unit and the concepts of hegemony, counter-hegemony and non-hegemony defined by Withanachchi et al. [14]. According to these authors, hegemony expresses a general consensus involving agreement on ideas that are supported by material resources and institutions. Dominant states and social forces base their ideological position on general principles that are accepted and approved by subordinated states and social forces [15]. These characteristics fit the idea of water management as a function of the river basin, as developing and transitional countries have developed their legal and institutional frameworks according to neoliberal marketing strategies, dictated by international financial institutions $[6,16]$. Such a measure was justified by the Brazilian government's financial crises and ineffective administration [17]. This happened in most of Latin American [6,17,18] and other emerging and transitional countries, for example, Mongolia [2,7]. 
However, hegemony can be fragile, and can be called into question. The nature of opposition backs a counter-hegemony, with opposition taking the form of maneuvers to subvert the mechanisms of ideological diffusion, and seek political consensus [14]. Grassroots organizations provide illustrative examples of counter-hegemony [19]. For instance, Hoogester et al. [20] show how peasant and indigenous communities in Ecuador have created multi-scale networks to defend their access to water, to maintain their autonomy, and to struggle for a voice in decision-making concerning their water rights.

Non-hegemony exists when practices are applied outside hegemony and do not challenge it. In other words, non-hegemony is formed by dispersed specific policies, that do not profess to change the existing hegemony [14]. They are valid at a local level, but to enter the national level, non-hegemony practices have to shift to counter-hegemony [14].

The current hegemony of using a river basin for water management engenders many challenges, including depoliticization, lack of representativeness and overlapping of functions. Depoliticization of water management occurs when the power of pre-established institutions is transferred to the river basin institutions. According to Graefe [8] (p. 26), "the river basin fetishism, the domination of the IWRM and governance concepts can be taken as a symptom of the depoliticization of water management. It has to be understood as an effort to create new environmental regions voided of political interests, political representations and overall of politics".

However, institutions created to increase management decentralization and the participation of local representatives are often characterized by limited power transfers and accountable representation of local communities [19], which hinders the implementation of their deliberations. The participation of watershed organizations in some Latin American countries can be contested mainly because the central government decides who can participate, as is the case in Mexico [21], whereby old institutions retain the power of decision, causing local communities to lose trust in national governments [22].

The new river basin institutions do not replace pre-existing ones. As a result, policy making, regulation and enforcement powers can be allocated among organizations [7], thereby increasing the complexity of the negotiations and leading to unclear division of functions [10].

These challenges vary with the type of institutions associated with the river basin in question, which may differ considerably in terms of format (councils, committees, agencies, etc.), goals (joint financing for hydraulic works, planning, conflict resolution, etc.), duration (fixed or undetermined, whether or not provided for in the legislation), decision-making and discretionary powers.

Some authors argue that the institutionalization of IWRM can cause difficulties of fit, horizontal interplay and vertical interplay $[7,12,23]$. Problems of fit result from a mismatch between hydrological and administrative borders $[1,7,8,24]$. Horizontal interplay focuses on the interaction of the multiple water-using sectors within a river basin, whereas vertical interplay concerns the coordination of institutions at local, regional and national levels [7].

One issue related to the scale misfit is the choice of the size of the river basin (or sub-basin). A large basin, involving multiple municipalities and regions, can make it difficult for certain actors to be present, and can even exclude certain stakeholders (particularly civil society), in addition to generalizing data and policies. However, the choice of a micro river basin has the disadvantage of losing a general overview.

The boundaries of water-use also differ considerably depending on each use, leading to horizontal interplay issues. Sometimes even one and the same water-use involves different boundaries. For example, in a given river basin, drinking water may be supplied to some municipalities by a supplier located in another river basin, and the water supplied may come from a source located in yet another a river basin. Thus, the multiple uses of water have fuzzy boundaries. What is more, using a river basin as the management and planning unit ignores the problem of pollution, the effects of globalization, and groundwater and watershed transfers, which are encountered in many regions $[4,8,10]$. Likewise, new institutions tend to render coordination between institutions more difficult, as "institutions 
at all levels have to be adjusted to avoid institutional disorder with overlapping responsibilities or policy gaps" [7] (p. 8). Vertical interplay problems are further addressed in the next section, since complex interactions among subnational, interstate and national spheres are accentuated in federal countries $[1,10]$.

At best, IWRM suggests both spatial fit and institutional (vertical and horizontal) interplay. However, since there is no perfect balance between the two [7], borders separating institutional systems are often not clear, and are difficult to identify precisely [23]. In general, the scale of the collective problem, of the actual problem experienced, and of the problem discussed do not correspond to the scale of the decision-making bodies $[1,11,12,24]$. On this subject, Nahrath et al. [24] introduced the concept of functional space (espace fonctionnel, in French), as a field in which there is a collective problem to be solved, that is politically recognized as such by public and private actors. It represents the social or geographic perimeter that is accepted as relevant to managing the said problem.

Similarly, the term "soft space", discussed by academics involved in spatial planning [25,26], illustrates the informal arrangements of spatial governance. It corresponds to a strategy for representing a geographical area that goes beyond political-administrative boundaries and internal territorial divisions [27]. "Soft spaces" oppose the notion of "hard spaces" as related to formal administrations. Space rescaling not only implies changes in powers across decision-making levels, it also involves new scales of intervention, new stakeholders and new geometries of governance [28].

Both the functional space and soft space concepts are analytical tools that make it possible to consider alternative formats of public action. As they are usually strategically formed by local public leadership, they are characterized by fuzzy boundaries and an intersectoral logic. More than functional, such spaces need to be coordinated with "hard spaces", seeking "a balanced composition of old and new structures" [7] (p. 7) that become spaces of functional interdependencies.

\section{Institutional Challenges in Federal Countries}

Federalism encompasses the idea of diversity in unity [29], even though not all diverse countries are federal, and not all federations are diversified [30]. Although there is no universal definition of federalism, authors generally agree that federal countries have some particularities and fundamental principles, as compared with unitary countries [29,31-33]. These principles are linked to the existence of a federal constitution that recognizes some legal and tax regulations, autonomy, and the sharing of competences with subnational levels. There is also a Lower House in addition to the Upper House, in order to guarantee regional representation during the central decision-making process.

The level of decentralization varies according to the delegation of the authority and the responsibility of subnational governments regarding legal competence, tax and legal regulations, and the execution of public policies [1]. Effective decentralization involves "an inclusive local process under local authorities empowered with discretionary decisions over resources that are relevant to local people" [19] (p. 5). In federal systems, the main challenge is to find the ideal balance between the resources and responsibilities of the national government, and the resources and responsibilities of the subnational governments. The federal level can try to reduce disparities and conflicts between the subnational levels by ensuring the supply of water and its fair allocation [12], especially in the case of unequal regions. Nevertheless, it can hinder implementation at the local level, since the person who executes the policy is not always the person who takes the decisions. Ribot [19] affirms that for decentralization to work properly, a strong central government is required, since it has roles in supporting a multiplicity of local efforts via finance and technical services.

Some authors distinguish between dual federalism, cooperative federalism and centralized federalism [34,35]. Dual federalism involves a clear separation of competences between national and subnational levels, like in the USA. Cooperative federalism involves cooperation between all government levels to accomplish tasks in different areas, as is the case in Switzerland and Germany, whereas in centralized federations, the federal government controls the majority of the subjects, with regards to financial resources and public policies, like in Venezuela. 
The main difference between unitary countries (even decentralized ones) and federations is that in unitary countries, the lower level governments are only statutory bodies whose existence can be questioned by the central government at any time [36]. According to Almeida [37], all democratic federations have mechanisms to ensure a level of "not total centralization", in conformity with the institutional and legal design.

The theoretical importance of federalism varies depending on the degree of decentralization [38]. The most decentralized federations also have a political system that is more complex than those of centralized federations, because in the first case a multitude of diverse regional and local policies are at play. Over time, federations may evolve linearly towards more centralized or more decentralized governments. However, in some cases, this process goes back and forth according to political and economic instabilities in their history. Some authors agree $[39,40]$ that federalism exists only in stable democracies, where democratic institutions and judicial and electoral systems work.

The strengthening of Latin American federalism is closely linked to the increase in democracy [39], since all of the federal Latin American countries (Argentina, Brazil, Mexico and Venezuela) recently had authoritarian governments, or currently have one (like Venezuela). The post-dictatorship period in these countries is related to the desire for public participation and the decentralization of powers in different sectors, including water management, as well as a mistrust of central governments [41]. However, Ribot [19] (p. 1) argues that "transferring power without accountable representation is dangerous". In those countries, there are still "power inbalances between federal and local governments" [42] (p. 42), with the predominance of top-down practices that hinder the accountability of participatory individuals [43]. In addition, under the pretext of decentralization, water and sewage systems have been privatized, particularly in Mexico [44].

One of the main challenges in the implementation of IWRM in federations is the problem of vertical interplay. The creation of new institutions hinders the coordination and division of powers. Particularly in more decentralized federations, where local governments are responsible for water management, top-down approaches are difficult to implement. However, federal countries need some mechanisms to ensure the coordination of actions and conflict resolutions in river basins that overlap other states.

Federations try to overcome issues of vertical interplay in different ways. In Argentina, the influence of the hegemonic model of IWRM is less pronounced than it is in the other Latin American federations, because the provinces hold the water rights and are responsible for water management. Argentina has no national water act; the World Bank tried to impose its creation, [6] but without success. The environmental regime of water law (25688/2002) contains the prescriptions of the World Bank, with only 10 articles, and establishes a hydrographic basin as a territorial water management unit. Nevertheless, it has not been applied since its promulgation, [45] and is the target of criticism, mainly in Mendoza province [46], because of the unconstitutionality of having delegated the power to dictate the resolutions to the national executive instead of to the provinces. However, $90 \%$ of the river basins are interprovincial, and since 1969, different river basin organizations have been created, mainly to share the cost of infrastructure [47]. There is also a national water plan, which was drawn up after three years of debates between the provinces and the federal government [48]. Even so, water management in the country is still fragmented, and conflicts between river basins are common [45].

According to Monsees [49], Germany has an alternative and varied format of interregional cooperation. Dating back to medieval times, the Water and Soil Associations (Wasser and Bodenverbände) organize collective action to manage water and land resources at a local level, against the hegemonic background of international standards. The associations for the management of the Ruhr basin (Ruhrverband and Ruhrtalsperrenverein), created in 1913, have influenced international water models, including the French [50] and the Brazilian [1] ones. Although they have not been established systematically throughout Germany, the Water Association Act of 1991 contains flexible rules for their operation. 


\section{The Development of Integrated Water Resources Management in Brazil and in Switzerland}

We now present the main features of IWRM implementation in a developing federal country (Brazil), and in a federation that is less dependent on international economics and is politically stable (Switzerland). The two countries share some features, including their multiculturality and relatively abundant water. However, federalism in the two countries differs considerably (highly autonomous regional and local governments in Switzerland, and more centralized ones in Brazil), size (Switzerland is approximately $0.5 \%$ the size of Brazil) and social equality (in 2017, the Brazilian Gini coefficient was 53.3, versus 32.3 in Switzerland) [51]. Table 1 summarizes the main characteristics and differences linked to water management in Brazil and Switzerland.

Table 1. Main characteristics of water resources management in Brazil and Switzerland.

\begin{tabular}{|c|c|c|}
\hline Criteria & Brazil & Switzerland \\
\hline System of governance. & Federal. & Federal. \\
\hline Regional features. & $\begin{array}{l}\text { Highly diverse in economic, } \\
\text { demographic, cultural and } \\
\text { environmental terms. }\end{array}$ & Multilingual diversity. \\
\hline Single national water policy. & Yes. Law 9433/97. & No. \\
\hline IWRM enshrined in law? & $\begin{array}{l}\text { Yes, in federal and state law. Such } \\
\text { laws are similar. }\end{array}$ & $\begin{array}{l}\text { Not at federal level. Certain } \\
\text { cantons are beginning to } \\
\text { incorporate the concept in their } \\
\text { legislation. Laws and experiences } \\
\text { differ considerably. }\end{array}$ \\
\hline $\begin{array}{l}\text { First experience of integrated } \\
\text { management based on a } \\
\text { river basin. }\end{array}$ & $\begin{array}{l}\text { 1978-Special Committee for } \\
\text { Integrated Basin Studies } \\
\text { (Comitê Especial de Estudos } \\
\text { Integrados de Bacias } \\
\text { Hidrográficas-CEEIBH) }\end{array}$ & 1984-Glatt Commission \\
\hline $\begin{array}{l}\text { Encouragement and interest for } \\
\text { the IWRM approach. }\end{array}$ & $\begin{array}{l}\text { Yes. At the federal, state and } \\
\text { watershed levels. }\end{array}$ & $\begin{array}{l}\text { Yes. At the federal level through } \\
\text { reports and guidelines. Variable } \\
\text { interest in the cantons. }\end{array}$ \\
\hline Territorial Management Unit. & River basin. & Mainly political-administrative. \\
\hline
\end{tabular}

\subsection{The Development of Integrated Water Resources Management in Brazil}

In contrast to many federal countries, the genesis of Brazilian federalism refers to the separation of units that were previously united (what Stepan [52] called "hold together federations"), as opposed to "come together federations", that aim to unite sovereign territories. In this way, Brazilian federalism emerged not because independent entities wanted it to happen, but because the decision was taken by the central government. Its genesis may explain the subsequent characteristics of intergovernmental relations, with strong control exerted by the federal government in defining public policies, as well as fiscal and legal regulations, in Brazil [10,53].

The development of Brazilian federalism has not been linear; rather, there have been periods of centralization followed by decentralization. Thus, if the military dictatorship (1964-1985) lacked democracy and political freedom, its end led local communities to distrust national government [22], and to fear the return of centralized power. This situation was a breeding ground for legal and institutional changes in many sectors, via decentralization and public participation [54], according to international principles.

With the Brazilian Federal Constitution of 1988, municipalities obtained the same status as the regional states and the federal government, which is not a common feature in federations. Municipalities can legislate, and are responsible for sanitation and land-use planning. However, at the time of writing, the Brazilian federalist model combines centralized power of decision with decentralized execution 
of public policies [10,53]. Despite efforts to give more power to local governments, states and municipalities still execute public policies that are decided by the federal government.

In the water sector, the 9433/1997 Water Act established the creation of watershed institutions (committees and agencies) aimed at decentralization and participation in decision-making, a process inspired mainly by the French model [1,55]. In the following years, the World Bank published a range of reports containing instructions for the implementation of the national water policy $[16,18,56]$.

Since the hegemonic model of IWRM in Brazil was adapted from fitting a unitary country (France) to fitting a federation, there are differences between the French and Brazilian water institutions. In France, the same policy applies throughout the country. In Brazil, each state lays down the rules governing the delimitation of the river basins. Water institutions were established over time, with some particularities (depending on the legislation of the state concerned) and before water agencies were created. Water agencies are agencies that execute the basin committee's decisions, with no political power or substantial flexibility. Unlike in France, the water charge system does not depend on consumption or pollution, but on granting water-use rights. The committee meetings are open to the public, which is not the case in France [57].

Although each state has its own water legislation, the water management model is similar across the country. Watershed committees (comprised of an equal number of voting members, usually federal, state and municipal members, water users, and the civil society such as NGOs and academics) are responsible for implementing the water management tools supplied by the national law. The water legislation follows the principles established by the GWP: public participation, the allocation of water rights, drawing up of plans and a water resources information system, and water charging at the watershed level (through an agency). Table 2 presents the main institutions, and their roles in water management and planning in Brazil.

Table 2. The main institutions and functions in water management and planning in Brazil.

\begin{tabular}{ccc}
\hline Level & Institution & $\begin{array}{c}\text { Main Functions in Water Management } \\
\text { and Planning }\end{array}$ \\
\hline \multirow{2}{*}{ Federal government } & National Water Resources Council. & $\begin{array}{c}\text { Consultative and deliberative institution for the } \\
\text { formulation of the national water plan. }\end{array}$ \\
\cline { 2 - 3 } & National Water Agency. & $\begin{array}{c}\text { Provides technical and administrative support to } \\
\text { basin committees. Grants water use rights and } \\
\text { decides charges for the use of raw water in } \\
\text { federal rivers. }\end{array}$ \\
\cline { 2 - 3 } State & Ministry of Environment. & National Water Resources Policy. \\
\cline { 2 - 3 } & State Water Resources Council. & $\begin{array}{c}\text { Consultative and deliberative institution for the } \\
\text { formulation of the state water plan. }\end{array}$ \\
\cline { 2 - 3 } & State Water Secretariat. & State water policy. \\
\hline River basin & Federal committee. & Consultative and deliberative institution. \\
\hline State committee. & $\begin{array}{c}\text { Basin plan, arbitration in the case of conflicts in } \\
\text { the basin, suggests charges for water-use rights. }\end{array}$ \\
\cline { 2 - 4 } & River basin agency. & Executive secretariat of the committee. \\
\hline Municipality & Varies with the municipality. & $\begin{array}{c}\text { Spatial planning, water supply and sewage } \\
\text { treatment, which may be delegated to private or } \\
\text { mixed economy enterprises. }\end{array}$ \\
\hline
\end{tabular}

Regional differences are huge in Brazil, since the regions with the smallest populations have the highest water availability (Amazon region), while areas with the highest population density (near to the coast) suffer from water scarcity [58]. However, state laws and management tools are similar throughout the country, and do not take local disparities into consideration, a fact noted by Gontijo [59], who evaluated nine case studies of river basin institutions in different regions of Brazil. 
One of the main challenges in putting watershed management into practice in Brazil is vertical interplay. Brazilian rivers are all public, but if they flow through more than one state they belong to the federal government, and to the state if they only flow through one state. Conversely, water planning is the responsibility of river basin institutions. This division was intended to reduce past competition between states through federal neutrality. Nevertheless, it created several practical obstacles to the implementation of integrated water management $[60,61]$. To give an example, the Piracicaba, Capivari and Jundiaí (PCJ) river basins in the State of São Paulo contain both federal and state rivers, resulting in three committees (São Paulo state, Minas Gerais state and the federal committee) in the same river basin. All the decisions must be taken by all three committees. If there are differences in the rules in Minas Gerais and São Paulo (e.g., on charging), the process stagnates [61].

The distribution of functions is not completely clear, since the federation and the states are responsible for water management in interstate river basins [60]. In addition to possible power (re)centralization, local stakeholders are often confused about federal or state control and leadership. In the opinion of some state water agencies, the role of the basin committee is to discuss environmental problems in the river basin and to implement the river basin plan, while management is assumed to be a task for the state water agencies. In the opinion of committee participants, management is also the responsibility of the committees, as they discuss and decide issues such as the amounts of water charges [1].

Interest in participating, and implementing the instruments provided for by law, varies among the committees. In those created by bottom-up initiatives (which are in the minority), there is strong engagement and interest on the part of local actors, and the implementation of actions is more advanced than in other committees [60]. This is the case of the PCJ Committees (since its creation, the participation of members from civil society, industry and governmental institutions at their meetings has more than doubled [1]), created from the experience of the PCJ Consortium, and formed by municipalities who voluntarily got together to finance water protection actions in their river basins. In other municipalities around the country, the top-down approach [60] led to limited participation, representativeness and effectiveness, even in river basins where there are major conflicts, such as in the Alto Tietê committee, in the metropolis of São Paulo [58].

The delimitation of the river basins by the committees does not primarily reflect hydrographical limits, but mainly strategic ones. In the case of the state of São Paulo, the government chose the water resources management units used for water planning in the state in the 1980s, before the state water law 7663/1991 was adopted. The Tietê River basin, which extends over $72,391 \mathrm{~km}^{2}$, was divided into six regions based on the economic and social issues of the time [1]. Its division was intended to be a functional space, but disregarded issues such as water transfers between basins, which today is a source of conflicts, especially during water crisis events [58].

The committees in Brazil did not lead to depoliticization, as reported by Graefe [8], who analyzed the creation of river basin institutions. However, in Brazil, their creation was accompanied by overlapping functions, especially in federal and state river basins, and a lack of accountable representation, since important decisions have since been neglected by public authorities. The committees are responsible for preparing the watershed plan aimed at the recovery and protection of the river basin. On the other hand, federal legislation compels municipalities to make plans related to water (such as a master plan for land-use and for sewage treatment) without being obliged to respect the river basin plan. This mismatch weakens the systematic implementation of integrated management, as formulated in the national water resources policy [62], which, in Article 3, mentions the need to "articulate water resources management with land use".

Integration does not mean the same as participation, but the two concepts are closely linked. IWRM implies that decisions are reached via a participatory approach. When questioned about the concept of integration, local actors tend to underline the importance of local participation in the decision-making process [1]. This lack of a clear definition [63] reflects the lack of such a definition of integration in the national water law. 


\subsection{The Development of Integrated Water Resources Management in Switzerland}

Switzerland has reasons to encourage a varied approach to IWRM besides increasing participation and decentralization, as it is already one of the most decentralized and participatory federations of the world [64]. The country was a confederation for five centuries, and since 1848 it has officially been a federation, even if official documents and citizens continue to use the term confederation. Cantons (subnational level states) have notable autonomy, which is one consequence of the country's federal origin, specifically, in the regrouping of sovereign states. There is also a belief that local power is better than power being exercised far away from citizens [65]. Thus, most areas of federal competence are decided and executed by the cantons and local municipalities. This local autonomy is reflected in the variety of water management systems in Switzerland [11].

In 1991, three new laws were adopted, whose aim was to integrate sectoral management (Federal Act on the Protection of Waters, Federal Fisheries Act and Federal Act on the Protection of Waters), reference [66] but to date, no interest has been shown in a single federal water law implementing the IWRM approach [11,67]. On the contrary, as the cantons are responsible for water management, there are as many water management models in Switzerland as there are cantons. This is the result of differences in regional priorities, and also the fact that municipal competencies vary with the canton. Table 3 lists the main institutions and their functions in water management and planning in Switzerland.

Table 3. The main institutions and their functions in water management and planning in Switzerland.

\begin{tabular}{ccc}
\hline Levels & Institutions & $\begin{array}{c}\text { Main Functions in Water Management and } \\
\text { Planning }\end{array}$ \\
\hline Central government & Federal Office for the Environment & $\begin{array}{c}\text { Principles concerning water uses, protection } \\
\text { and prevention against damaging } \\
\text { water actions }\end{array}$ \\
\hline Canton & Varies with the canton & $\begin{array}{c}\text { Control and monitoring role. Responsible for } \\
\text { water protection, water allocation, } \\
\text { and river management. }\end{array}$ \\
Municipality & Varies with the canton & $\begin{array}{c}\text { In most cantons, the municipality is } \\
\text { responsible for local spatial planning and } \\
\text { water supply and sewage (almost entirely } \\
\text { public all over Switzerland). }\end{array}$ \\
\hline
\end{tabular}

Participation is guaranteed by instruments established by the Federal Constitution. Compulsory referendum, facultative referendum and popular initiative, all found at the federal, cantonal and municipal levels, ensure citizen participation in the constitution and in changes in laws in different domains. One example is that Switzerland is not a member of the European Union, because the Swiss population did make the decision to not join it.

The particularities of the Swiss IWRM approach are as follows: the low level of influence of a single international model, the informality of the system, its approach based on priorities, and diversity. The country is flexible when choosing its water management model, which is dependent on local interests. This may be because Switzerland is not a member of the European Union, and it is not economically dependent on international institutions, such as the World Bank.

In the last two decades, the Swiss Confederation has tried to persuade cantons of the importance of using an IWRM approach throughout the country in official reports and documents $[67,68]$. According to these instructions, the IWRM approach accounts for multiple sectors during project development. In contrast to the international IWRM model, the Confederation encourages the concept with reservations. IWRM has multiple possible interpretations and formats, generally representing a priority approach. It is justified only by specific projects requiring real intersectoral coordination [69]. Furthermore, the perimeter of the IWRM is not necessarily the river basin [11], and river basin management should not always cover multiple water uses. Briefly, in Switzerland, the IWRM approach 
focuses more on goals than on the format. In other words, it is a tool that can be used in case of a serious need for coordination between uses.

Unlike in Brazil, the challenges to the implementation of IWRM in Switzerland are less linked to decentralization and involvement, because democratic rights are enshrined in the Constitution. Some stakeholders consider that more participation could lead to more bureaucracy, and slow down the process [61]. Difficulties rather concern inter-cantonal collaboration, the slowness of the process, and the difficulty in changing from micro-management (small municipalities) to a regional view of water management. As the strategy of persuasion implemented by the federal state is slow, water management in the country is still mainly sectoral today. Thus, despite efforts by the Confederation, water management is still fragmented among different territorial institutions at the local, regional and federal levels, as well as between different sectors. This fragmented view of water management is also reflected in the lack of centralized water databases, as most information is held by cantons and municipalities as a function of the sector [61]. This can involve additional costs and a lack of regional overview.

According to studies financed by the Swiss National Science Foundation (SNSF) $[69,70]$, an integrated water management approach is still emerging, and there is no ideal model, since each example examined differs depending on its local context. This leads us to conclude that there is no interest in river basin institutions throughout Switzerland for four main reasons: (i) Regional and local stakeholders (especially in municipalities and cantons) believe there is no water crisis, or any massive conflicts between water uses in the watersheds (regime of water abundance); (ii) The perimeters of uses differ with each use. For instance, it is quite common to have one water treatment plant shared by several small municipalities, whereas drinking water suppliers serve other municipalities; (iii) Public stakeholders tend to think that the creation of participatory groups could mean more hours of discussion and less execution. This is because public tools for participation already exist in Switzerland (referendum and initiative rights). It would require no effort to adapt existing sectoral partnerships so they incorporate new uses, as opposed to creating new ones; (iv) Municipalities are afraid of being powerless in the face of a new decision-making body. Even if only public stakeholders are involved, competence sharing would be complicated.

Although different from Brazil and less controversial, the Swiss water rights system is also complex. Waters can be public (cantonal or municipal, but not federal) or private depending on their nature: according to the Federal Constitution, the Swiss Civil Code (CC), and several national and cantonal laws [71], groundwater is private and linked to land ownership (art. 704 CC) [72], whereas surface waters and glaciers are public, cantonal or municipal, or private (depending on the canton). Usually in hydraulic and irrigation sectors, acquired use rights (managed through a system of concessions) refer to the previous judicial system, rather than to current laws.

\section{IWRM in Federal Countries}

The factors that influence the implementation of IWRM in federal countries are (i) the type of federalism, based on the level of autonomy of the subnational governments from the central government; (ii) the political history, i.e., the existence of a stable democracy or, on the contrary, the presence of authoritarian governments in some period of the country's history; and (iii) economic development and the varying degree of dependence on international institutions. Thus, although the normative concept of IWRM is disseminated globally, the format, objectives and reasons for adopting the IWRM approach differ considerably from one federation to another.

Decentralized federal countries have substantial local autonomy concerning the legal, fiscal and legislative system, and the implementation of public policies. Similarly, they represent more varied experiences of IWRM implementation, depending on local priorities. This is because subnational governments have more autonomy in these areas, and the solutions for local problems will consequently differ, which is the case in Switzerland, a highly decentralized country, financially and politically independent from other countries (even those of the European Union). The concept of IWRM is 
disseminated by persuasion, from federal to regional and local levels, and after consensus is reached between cantonal and local actors. The high level of local autonomy reveals a case of non-hegemony, with relatively dispersed and fragmented water management.

In more centralized federations, like Brazil, subnational levels depend to a great extent on the federal government. Decisions are often made at the national level and then applied relatively homogeneously at regional and local levels. The water management instruments provided by federal law, including plans and information systems, also exist at the state level, reflecting the hegemony of the international IWRM model in the country.

The main challenge for the implementation of IWRM in Brazil is effective decentralization and participation. River basin institutions were mainly created using a top-down approach, and the committees have little power of decision [1,10]. River basin plans, when they exist, are not fully executed, because municipalities are not obliged to follow them. River basin institutions have not solved and, on the contrary, have even accentuated the problem of vertical interplay, mainly due to the existence of double water rights, which has increased the number of institutions and highlighted the lack of coordination between the institutional levels.

In Switzerland, there are relatively few water institutions compared to Brazil, and their functions are more clearly defined. However, the problem of horizontal interplay is quite strong due to the fragmentation and sectorization of local institutions. Power is concentrated locally in small communes, and there is a lack of overview [11]. Therefore, the main challenge is the regionalization and coordination of decision-making, which has historically been dispersed. This fragmented view of water management is reflected in the dispersion of water databases, where information is scattered across different sectors and municipalities.

On the one hand, the water management model in Brazil is more formal and full-bodied, but there is a lack of pragmatism in the application of the planned instruments. On the other hand, the Swiss system is very informal, but managers are pragmatic when working on projects and focusing on the achievement of objectives, rather than the elaboration of multiple plans.

\section{Conclusions}

This article focused on some problems involved in implementing the IWRM model, as disseminated by international institutions in federations. Even though it is a normative concept, in federal countries, the interests in and challenges for its implementation may vary depending on the type of federalism, i.e., the degree of subnational autonomy, the history of authoritarian governments and the country's dependence on international institutions.

The Brazilian and Swiss cases reveal different experiences of IWRM, reflecting their political, historical and economic characteristics. On the one hand, Brazil represents non-linear federalism, with periods of less centralization alternating with periods of greater centralization, particularly during the dictatorship. Local and regional governments struggle to decentralize water governance and to implement participatory institutions according to a hegemonic model. Water management follows the same model throughout the country.

On the other hand, Swiss federalism involves more decentralization due to the autonomy of the subnational levels, in particular the municipal level, and the fact that public participation is guaranteed by the constitution. The concept is interpreted differently, which is linked to the coordination of certain areas during specific projects. The result is a large number of diverse cases of non-hegemony across the country.

Author Contributions: Conceptualization, G.M.M. and E.R.; methodology, G.M.M. and E.R.; investigation, G.M.M.; resources, G.M.M.; writing—original draft preparation, G.M.M.; writing—review and editing, G.M.M. and E.R.; visualization, G.M.M.; supervision, E.R. All authors have read and agree to the published version of the manuscript. 
Funding: This research was funded by the Swiss Government Excellence Scholarships for Foreign Scholars and Artists Program, grant number 2012.0612 and the Brazilian National Council for Scientific and Technological Development (CNPq), program "Ciência sem fronteiras", grant number 248808/2013-3.

Acknowledgments: The authors are grateful to the reviewers for their careful reading of the text and useful suggestions. We are also grateful to the Swiss Government Excellence Scholarships for Foreign Scholars and Artists Program and the Brazilian program "Ciência sem fronteiras".

Conflicts of Interest: The authors declare no conflict of interest.

\section{References}

1. Miranda, G.M. Gestion Intégrée des Ressources en Eau Dans les Pays Fédéraux: Les Cas Suisse et Brésilien; Université de Lausanne: Lausanne, Switzerland, 2017.

2. Withanachchi, S.; Ghambashidze, G.; Kunchulia, I.; Urushadze, T.; Ploeger, A. A Paradigm Shift in Water Quality Governance in a Transitional Context: A Critical Study about the Empowerment of Local Governance in Georgia. Water 2018, 10, 98. [CrossRef]

3. Libanio, P.A.C. Two decades of Brazil's participatory model for water resources management: From enthusiasm to frustration. Water Int. 2018, 43, 494-511. [CrossRef]

4. Saravanan, V.S.; McDonald, G.T.; Mollinga, P.P. Critical review of Integrated Water Resources Management: Moving beyond polarised discourse. Nat. Resour. Forum 2009, 33, 76-86. [CrossRef]

5. GWP. La Gestion Intégrée des Ressources en Eau; Global Water Partnership: Stockholm, Sweden, 2000.

6. World Bank. Argentina Water Resources Management Policy Elements for Sustainable Development in the XXI Century; World Bank: Washington, DC, USA, 2000.

7. Horlemann, L.; Dombrowsky, I. Institutionalizing IWRM in Developing and Transition Countries-The Case of Mongolia. Environ. Earth Sci. 2012, 65, 1547-1559. [CrossRef]

8. Graefe, O. River basins as new environmental regions? The depolitization of water management. Procedia Soc. Behav. Sci. 2011, 14, 24-27. [CrossRef]

9. Withanachchi, S.S.; Houdret, A.; Nergui, S.; Ejarque Gonzalez, E.; Tsogtbayar, A.; Ploeger, A. (Re)configuration of Water Resources Management in Mongolia A Critical Geopolitical Analysis.; Kassel University Press: Kassel, Germany, 2014; ISBN 978-3-86219-860-3.

10. Empinotti, V.L.; Gontijo, W.C.; de Oliveira, V.E. Federalism, water, and (de)centralization in Brazil: The case of the São Francisco River water diversion. Reg. Environ. Chang. 2018, 18, 1655-1666. [CrossRef]

11. Buchs, A. Integrated Water Resources Management as a Compromise: Renewing the Water Act in the Canton of Fribourg, Switzerland. In A Critical Approach to International Water Management Trends; Bréthaut, C., Schweizer, R., Eds.; Palgrave Macmillan: London, UK, 2018; pp. 45-69.

12. Lebel, L.; Garden, P.; Imamura, M. The Politics of Scale, Position, and Place in the Governance of Water Resources in the Mekong Region. EES 2005, 10, art18. [CrossRef]

13. Swyngedouw, E. Scaled Geographies: Nature, Place, and the Politics of Scale. In Scale and Geographic Inquiry; Sheppard, E., McMaster, R.B., Eds.; Blackwell Publishing Ltd.: Malden, MA, USA, 2004; pp. 129-153. ISBN 978-0-470-99914-1.

14. Withanachchi, S.; Köpke, S.; Frettsome, D. Building Non-Hegemonic Political Culture for Sustainable Rural Development. In Future of Food State of the Art, Challenges and Options for Action; Albrecht, S., Braun, R., Heuschkel, Z., Mari, F., Pippig, J., Eds.; Oekom: München, Germany, 2013; pp. 231-241.

15. Cox, R. Gramsci, hegemony and international relations: An essay in method. In Gramsci, Historical Materialism and International Relations; Gill, S., Ed.; Cambridge University Press: Cambridge, UK, 2018; pp. 44-66.

16. Scantimburgo, A.L. O Banco Mundial e a Política Nacional de Recursos Hídricos; Cultura Acadêmica: São Paulo, Brazil, 2013.

17. Mussetta, P. Participación y gobernanza. El modelo de gobierno del agua en México. Espac. Públicos 2009, 12, 66-84.

18. Banco Mundial. Estratégias de Gerenciamento de Recursos Hidricos: Áreas de Cooperação Com o Banco Mundial; Série Agua Brasil; Banco Mundial: Brasilia, Brazil, 2003.

19. Ribot, J.C. Democratic Decentralization of Natural Resources. In Beyond Structural Adjustment; Van De Walle, N., Ball, N., Ramachandran, V., Eds.; Palgrave Macmillan US: New York, NY, USA, 2003; pp. 159-182. ISBN 978-1-4039-6317-8. 
20. Hoogesteger, J.; Boelens, R.; Baud, M. Territorial pluralism: Water users' multi-scalar struggles against state ordering in Ecuador's highlands. Water Int. 2016, 41, 91-106. [CrossRef]

21. Parra-Armenta, E.M.; Salazar Adams, A. La gestión integral del agua en dos consejos de cuenca del noroeste de México. Entreciencias 2017, 5. [CrossRef]

22. Zurbriggen, C. Gobernanza: Una mirada desde América Latina. Perf. Latinoam. 2011, 19, 39-64.

23. Young, O.R. The Institutional Dimensions of Environmental Change-Fit, Interplay, and Scale; MIT Press: London, UK, 2002.

24. Nahrath, S.; Varone, F.; Gerber, J.-D. Les espaces fonctionnels: Nouveau référentiel de la gestion durable des ressources? Vertigo 2009. [CrossRef]

25. Allmendinger, P.; Haughton, G. Soft spaces, fuzzy boundaries and metagovernance: The new spatial planning in the Thames Gateway. Environ. Plan. 2009, 41, 617-633. [CrossRef]

26. Allmendinger, P.; Haughton, G.; Knieling, J.; Othengrafen, F. Soft Spaces in Europe: Re-Negotiating Governance, Boundaries and Borders; Routledge: New York, NY, USA, 2015.

27. Pettersson, F.; Frisk, H. Soft space regional planning as an approach for integrated transport and land use planning in Sweden-Challenges and ways forward. Urban Plan. Transp. Res. 2016, 4, 64-82. [CrossRef]

28. Dominic, S. European Integration and Spatial Rescaling in the Baltic Region: Soft Spaces, Soft Planning and Soft Security. Eur. Plan. Stud. 2014, 22, 680-693. [CrossRef]

29. Croisat, M. Le Fédéralisme en Europe; Montchrestien: Paris, France, 2010; ISBN 978-2-7076-1669-2.

30. Moreno, L.; Collino, C. Diversity and Unity in Federal Countries; Mc Gill-Queen's University Press: Quebec, QC, Canada, 2005; ISBN 10: 0773537392.

31. Anderson, G. Federalism: An Introduction; Oxford University Press: Ontario, ON, Canada, 2008; ISBN 978-0-19-542904-6.

32. Saint-Ouen, F. Le Fédéralisme; Infolio éditions: Paris, France, 2005; ISBN 10: 2884749071.

33. Segado, F.F. Le fédéralisme en Amérique latine. Politeia 2004, 1-19.

34. Briant, V. Contribution à l'étude des «arrangements fédératifs», de l'État fédéral à l'État unitaire décentralisé. Fédéralisme Régionalisme 2009, 9.

35. Liziero, L.B.; Carvalho, F. Federalismo e centralização no Brasil: Contrastes na construção da Federação Brasileira. Rev. Direito Cid. 2018, 10. [CrossRef]

36. Pfeiffer, K.; Weber, L. Le fédéralisme suisse à l'épreuve du temps: Un modèle pour l'Europe? Polit. Manag. Public 1991, 9, 103-138. [CrossRef]

37. Almeida, M.H.T. Recentralizando a federação? Rev. Sociol. Política 2005, 24, 29-40. [CrossRef]

38. Gibson, E.L. Federalism and Democracy in Latin America.; The Johns Hopkins University Press: Baltimore, MD, USA, 2004.

39. Bizberg, I. Variedades del Capitalismo en América Latina: Los Casos De México, Brasil, Argentina y Chile; El Colegio de Mexico: Ciudad de Mexico, Mexico, 2015.

40. Posner, G. Le Fédéralisme, Recette Pour une Démocratie Efficace. Available online: http://www.taurillon.org/ 6286 (accessed on 10 October 2017).

41. Trillo, F.H. Federalismo Ambiental em America Latina: Una Revisión; Naciones Unidas, CEPAL, Union Europea, Naciones Unidas: Santiago, Chile, 2015.

42. Wilder, M. The Human Right to Water in Mexico: Challenges and Opportunities. Water Altern. 2020, 13, 28-48.

43. Ferro, M. Participación ciudadana y gestión ambiental en la cuenca Matanza-Riachuelo, Argentina. Agua Territ. 2017, 58. [CrossRef]

44. Espinosa, M.H.A. La privatización del agua: Impacto de las concessiones de agua em Texcoco, estado de México, México. Rev. Científica CODEX 2015, 1, 91-105.

45. OECD. Water Governance in Argentina; OECD Studies on Water; Editions OECD: Paris, France, 2019.

46. Rovere, M. Argentina. In Gobernanza del Agua en América del Sur: Dimensión Ambiental; Iza, A., Rovere, M.B., Eds.; Económica y Desarrollo, Unión Mundial para la Naturaleza: Gland, Cambridge, UK, 2006; pp. $25-87$.

47. Adler, F.J. El futuro del Agua en Tucumán; Editorial de la Universidad Nacional de Tucumán: Tucumán, Argentina, 2014.

48. ARGENTINA. Plan Nacional del Agua. Available online: https:/www.argentina.gob.ar/sites/default/files/ 2017-09-29_pna_version_final_baja_0.pdf (accessed on 10 October 2018). 
49. Monsees, J. The German Water and Soil Associations-Self-governance for small and medium scale water and land resources management. J. Appl. Irrig. Sci. 2000, 39, 19.

50. Barraqué, B. Les politiques de l'eau en Europe. Rev. Française Sci. Polit. 1995, 45, 420-453. [CrossRef]

51. World Bank World Development Indicators. Available online: https://databank.worldbank.org/reports.aspx? source $=2 \&$ series $=$ SI.POV.GINI\&country (accessed on 18 March 2020).

52. Stepan, A. Toward a new comparative politics of federalism, multinationalism, and democracy: Beyond Rikerian federalism. In Federalism and Democracy in Latin America; Gibson, E., Ed.; Baltimore, Johns Hopkins University Press: Baltimore, MD, USA, 2004; pp. 29-84.

53. Arretche, M. Democracia, Federalismo e Centralização no Brasil; Fiocruz: Rio de Janeiro, Brazil, 2012.

54. Rolnik, R.; Ribeiro, A.C.T.; Vaz, L.F.; Silva, M.L.P. 10 Anos do Estatuto da Cidade: Das lutas pela reforma urbana às cidades da copa do mundo. In Quem Planeja O Território? Atores, Arenas e Estratégias; Ribeiro, A.C.T., Vaz, L.F., Silva, M.L.P., Eds.; Letra Capital, ANPUR: Rio de Janeiro, Brazil, 2012; pp. 87-104. ISBN 978-85-7785-182-9.

55. Cunha, E.C.N.; Veiga, A.P.; Knieling, J. Domínio e competência sobre os recursos hídricos no Brasil. Rev. Justiça Cid. 2004, 45, 1-5.

56. World Bank Management of Water Resources: Bulk Water Princing in Brazil; World Bank: Washington, DC, USA, 1999.

57. Laigneau, P.; Formiga-Johnsson, R.; Barraqué, B. Les agences de l'eau au Brésil et en France: Les défis d'une gestion de l'eau en tant que bien commun à l'échelle des bassins versants. Ann. Mines Responsab. Environ. 2018, 4, 50-54. [CrossRef]

58. Victor, D.G.; Almeida, P.; Wong, L. Water Management Policy in Brazil. SSRN J. 2015. [CrossRef]

59. Gontijo, W.C. Uma Avaliação Da Política Brasileira De Recursos Hídricos Baseada Em Dez Casos De Estudo; Universidade de Brasilia: Brasilia, Brazil, 2013.

60. Gontijo, W.C.; Trigo, A.J. Domínio das águas no Brasil e a gestão integrada por bacia hidrográfica: Reflexões sobre o modelo vigente no Brasil. In Proceedings of the Anais do $4^{\circ}$ Encontro Internacional da Governança da Água, São Paulo, Brazil, 24-26 September 2013; pp. 98-108.

61. Miranda, G.M. Motivações e desafios para a implementação da gestão integrada de recursos hídricos em federações: Os casos brasileiro e suíço. Rev. Gestão Agua América Lat. 2020, 17.

62. Brasil. Política Nacional de Recursos Hídricos; Secretaria de Recursos Hídricos: Brasília, Brazil, 1997.

63. Libânio, P.A.C. The use of goal-oriented strategies in the building of water governance in Brazil. Water Int. 2014, 39, 401-416. [CrossRef]

64. Church, C.; Dardanelli, P. The dynamics of confederalism and federalism: Comparing Switzerland and the EU. Reg. Fed. Stud. 2005, 15, 163-185. [CrossRef]

65. Dardanelli, P. Federal Democracy in Switzerland; Routledge Series in Federal Studies; Routledge: London, UK, 2010; ISBN 0-415-55548-5.

66. Musy, A.; Higy, C.; Reynard, E. Hydrologie 1: Une Science de la Nature: Une Gestion Sociétale; Presses polytechniques et universitaires romandes (PPUR): Lausanne, Switzerland, 2014; ISBN 102880745462.

67. Zysset, A.; Pfammatter, R.; Hugi, C.; Zichel, B. Gestion des Eaux en Suisse: Analyse Systémique; Office fédéral de l'environnement: Berne, Switzerland, 2007.

68. Dübendorfer, C.; Tratschin, R.; Urfer, D.; Zahner, S.; Zysset, A. Gestion par Bassin Versant. Guide Pratique Pour une Gestion Intégrée des Eaux en Suisse; Office fédéral de l'environnement, OFEV: Berne, Suisse, 2012.

69. Comité de Direction du PNR 61. Gestion Durable de L'eau en Suisse: Le PNR61 Montre les Voies à Suivre Pour L'avenir. Synthèse Globale dans le Cadre du Programme National de Recherche "Gestion Durable de L'eau"; PNR61: Berne, Switzerland, 2015; ISBN 978-3-7281-3613-8.

70. Balsiger, J.; Menzel, S. Auf dem Weg zu Einer Integrierteren Wasserpolitik in der Schweiz: Kantonale Koordinationsformen und - Mechanismen. Teilbericht zum Arbeitspaket 2.1 des Projekts IWAGO_Integrated Water Governance with Adaptive Capacity in Switzerland; Eidgenössische Technische Hochschule, Eawag: Zürich, Dübendorf, Switzerland, 2012; ISBN 978-3-8383-2463-0. 
71. Reynard, E.; Mauch, C.; Thorens, A. Développement historique des régimes institutionnels de l'eau en Suisse entre 1870 et 2000. In Institutionnelle Regime für Natürliche Ressourcen: Boden, Wasser und Wald im Vergleich; Knoepfel, P., Kissling-Näf, I., Varone, F., Eds.; Helbing \& Lichtenhahn: Basel, Frankfurt, Germany, 2001; pp. 131-139. ISBN 3-7190-2063-0.

72. Varone, F.; Reynard, E.; Kissling-Näf, I.; Mauch, C. Institutional Resource Regimes. The case of water in Switzerland. Integr. Assess. 2002, 3, 78-94. [CrossRef]

(C) 2020 by the authors. Licensee MDPI, Basel, Switzerland. This article is an open access article distributed under the terms and conditions of the Creative Commons Attribution (CC BY) license (http://creativecommons.org/licenses/by/4.0/). 